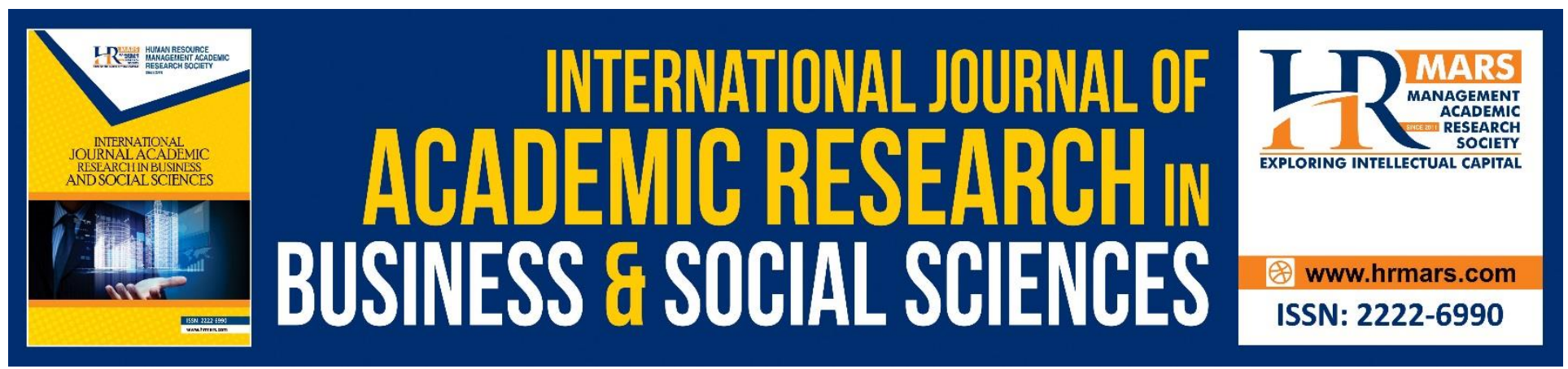

\title{
The Human Factors Communicating Towards a Sustaining Quality Management System in Military Organization
}

\author{
W.L. Wong, Hasan Al-Banna Mohamed, Jessica Ong Hai Liaw, Norlaila \\ Mazura Mohaiyadin, Hilmi Azani Husain
}

To Link this Article: http://dx.doi.org/10.6007/IJARBSS/v9-i1/5863

DOI: $10.6007 /$ IJARBSS/v9-i1/5863

Received: 12 Dec 2018, Revised: 30 Dec 2019, Accepted: 16 Jan 2019

Published Online: 27 Jan 2019

In-Text Citation: (Wong, Mohamed, Liaw, Mohaiyadin, \& Husain, 2019)

To Cite this Article: Wong, W. L., Mohamed, H. A.-B., Liaw, J. O. H., Mohaiyadin, N. M., \& Husain, H. A. (2019). The Human Factors Communicating Towards a Sustaining Quality Management System in Military Organisation. International Journal of Academic Research Business and Social Sciences, 9(1), 1322-1331

Copyright: (C) 2019 The Author(s)

Published by Human Resource Management Academic Research Society (www.hrmars.com)

This article is published under the Creative Commons Attribution (CC BY 4.0) license. Anyone may reproduce, distribute, translate and create derivative works of this article (for both commercial and non-commercial purposes), subject to full attribution to the original publication and authors. The full terms of this license may be seen

at: http://creativecommons.org/licences/by/4.0/legalcode

Vol. 9, No. 1, 2019, Pg. 1322 -1331

http://hrmars.com/index.php/pages/detail/IJARBSS

JOURNAL HOMEPAGE

Full Terms \& Conditions of access and use can be found at http://hrmars.com/index.php/pages/detail/publication-ethics 


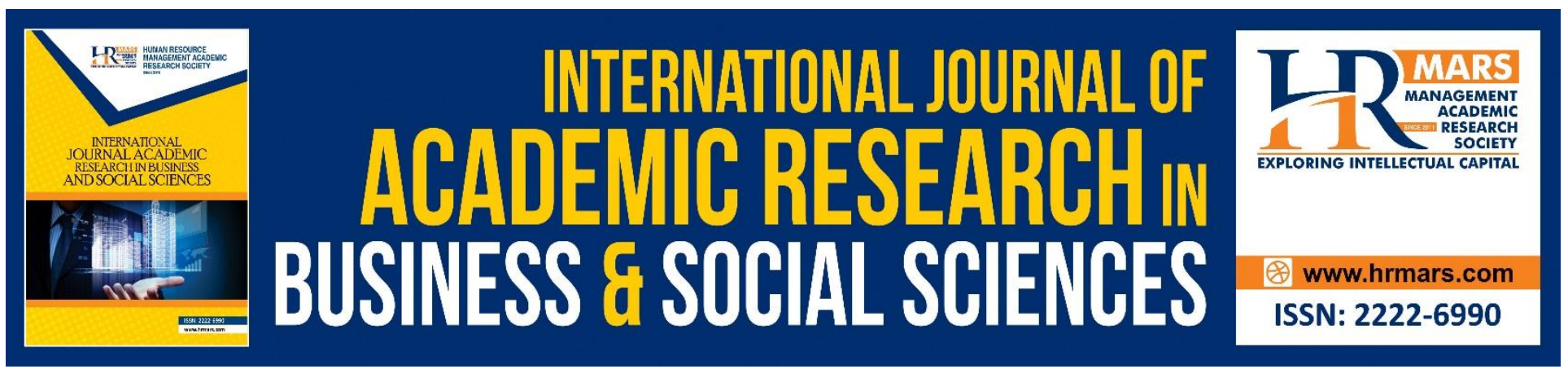

\title{
The Human Factors Communicating Towards a Sustaining Quality Management System in Military Organization
}

\author{
W.L. Wong, Hasan Al-Banna Mohamed, Jessica Ong Hai Liaw, \\ Norlaila Mazura Mohaiyadin
}

Faculty of Defence Studies and Management, National Defence University of Malaysia, Malaysia

\author{
Hilmi Azani Husain \\ Language Centre, National Defence University of Malaysia, Malaysia
}

\begin{abstract}
The purpose of this study is to identify the human factors communicating towards a sustaining quality management system (QMS) for military organisation in Malaysia. Through a comprehensive literature review on QMS, this study had identified several human factors which are significant factors in sustaining QMS for military organisation. Questionnaire items were developed for this quantitative research to identify the relationship between these human factors and QMS in military organisation. A total of 350 questionnaires were distributed to respondents from military organisation all over Peninsular Malaysia which are implementing QMS at formation and unit. All data were analysed using Statistical Package for the Social Sciences (SPSS) version 23 and the results revealed that leadership commitment, employee participation, training and; reward and recognition are the human factors communicating towards sustainable QMS in military organisation. This study is expected to assist military organisation in Malaysia to improve its QMS in managing human resources and military assets in order to strengthen its strategic requirement. This study contributes to a better understanding in implementing QMS within the military context in Malaysia.
\end{abstract}

Keywords: Human Factors, Quality Management System, Leadership Commitment, Employee Participation, Training, Reward and Recognition.

\section{Introduction}

Over the past years, military organisation in Malaysia has become a focus of interest for government organisations and management researchers, along with the awareness of the important role it has played in the global security. Presently, many researchers have been involved in conducting research projects in relation to military in various fields such as culture, organisational studies, technology transfer and marketing. Research on military organisation quality management domain in Malaysia, 
however, has not attracted much attention. As a result, limited research has been conducted in this field, especially on sustaining quality management system (QMS) in military organisation. Currently, limited empirical survey has been conducted to study the relationship of human factors (soft factors) with QMS. The lack of sufficient findings have contributed to a number of ineffective QMS in military organisation.

From the literature, it has identified the key human factors for sustaining QMS in organisation. The human factors are the behavioural aspects of management such as leadership, human resource management (HRM), employee's involvement and empowerment (Ahmad et al., 2013). Several scholars have identified the human factors in quality management which have a positive influence on QMS (Daud, Jamaludin, \& Ramanr, 2012). Alongside with these studies, there were also some other general studies that had been carried out specifically in Malaysian context which have also identified the human factors related to QMS such as leadership, employee training, communication, employee reward and education (Ahmad et al., 2013).

Through this study, new knowledge is generated from existing QMS domain integrated with the behaviour of military organisation. After reviewing the existing literature, it has become clear that leadership commitment, employee's participation, training and; reward and recognition are related to QMS in military context in Malaysia. Hence, these human factors are the key to sustaining QMS because they have a positive impact on organisational performance.

\section{Research Objectives}

a. To identify the relationship between leadership commitment, employee's participation, training and; reward and recognition with QMS for military organisation in Malaysia.

b. To identify to what extent the human factors related to QMS for military organisation in Malaysia.

\section{Literature Review}

\section{Leadership Commitment}

Leadership is the ability to inspire confidence and support among those needed to achieve organisational goals. Ab Wahid (2010) explained the concept of leadership as: The ability of top management to establish, practice, and lead a long-term vision for the firm, driven by changing customer requirements, as opposed to an internal management control role. Leadership is thus exemplified by clarity of vision, long-term orientation, coaching management style, participative change, employee's empowerment, and planning and implementing; organisational change (Ahmad et al., 2013). According to Juran (1999), certain roles of top management can be identified as: Establish quality policies, establish and deploy quality goals, provide resources, provide problemoriented training, and stimulate improvement. Davies (2004) recognised the crucial role of leadership in creating the goals, values and systems that guide the pursuit of continuous performance improvement. Recognition of the critical role of leadership and its responsibility in pursuit of continuous quality improvement echoes the arguments put forward by quality gurus such as Deming (1986) and Juran (1999). Thus, the concept of leadership in this study can be defined as the ability of top management to lead the firm in continuously pursuing long-term overall business success. This is exemplified by top management participation, top management encouragement, employee's 
INTERNATIONAL JOURNAL OF ACADEMIC RESEARCH IN BUSINESS AND SOCIAL SCIENCES Vol. 9, No. 1, Jan, 2019, E-ISSN: 2222-6990 @ 2019 HRMARS

empowerment, top management learning, top management commitment to employee's education and training; and top management pursuit of product quality and long-term business success.

\section{Employee's Participation}

Employee's participation can be defined as the degree to which employees in a firm engage in various quality management (QM) activities (Zahid, 2014). By personally participating in QM activities, employees acquire new knowledge, see the benefits of the quality disciplines, and obtain a sense of accomplishment by solving quality problems. Participation is decisive in inspiring action on QM (Juran, 1999). Employee's participation is exemplified by things such as teamwork, employee's suggestions, and employee's commitment. A remarkable characteristic of employee's participation is teamwork and within-functional teams. The aim of a team is to improve the input and output of any stage (Ali, 2013). A team may well be composed of people from different staff areas, everyone having a chance to contribute ideas, plans and figures. Teamwork is sorely needed throughout the firm and it can compensate one's strength for another's weakness (Deming, 1986).

Group work and group decision-making offer several advantages over individual effort. If several knowledgeable people are brought into the decision-making process, a number of worthwhile possibilities may be uncovered making synergy a possible benefit. Group members often evaluate each other's thinking, thus the team is likely to avoid major errors (Samat, 2004). Cross-functional quality teams and task forces are among the most common features of QM firms. Teamwork can be characterised as collaboration between managers and non-managers, between different functions (Ooi, Bakar, Arumugam, Vellapan, \& Loke, 2007). Teamwork practices include identifying the needs of all groups and firms involved in decision-making, trying to find solutions that will benefit everyone involved and sharing responsibility and credit. Such practices are often implemented by forming teams. Al-Ababneh (2011) stated that the single most commonly used QM implementation practice is formation of short-term problem-solving teams.

Problem-solving teams work on a wide variety of tasks, ranging from cross- functional involvement in tackling quality problems related to many functional departments to solving withinfunctional quality problems. Zhang (2000) suggested that internal cooperation among employees enables higher individual performance by creating mutually beneficial situations among organisational members and between organisational members and the firm as a whole.

\section{Training}

Training refers to the acquisition of specific skills or knowledge (Zahid, 2014). Training programs attempt to teach employees how to perform particular activities or a specific job. Zhang (2000) suggested that training requires a systematic approach. The development of a sound training program requires systematically gathering data about the employees or the firm's needs. A good assessment includes an analysis of the following:

a. How well the firm is achieving its goals.

b. The skills needed by the workforce to accomplish these goals.

c. Strengths and weaknesses of the current workforce. 
A careful analysis of these items provides valuable information to design effective training activities. Investment in training is vitally important for ensuring the success of education and training programs. According to Mustafa (2015), training is the second most commonly used QMS practice in the United States. Firms that implement QMS invest heavily in training for employees at different levels. Deming (1986) spoke often of the importance of properly training workers in performing their work. Otherwise, it is difficult to improve their work. The cross-functional quality teams among the characteristics of QMS firms stack the cards in favour of learning by the simple fact that they are cross-functional; individual members are exposed to more, and more diverse points of view than would be the case if they worked mostly by themselves or in within-functional teams.

Learning is the ability and willingness of the firm to engage in learning or knowledge seeking activities at the individual, group or team, and organisational levels (Toga, 2017). In order to have effective learning activities, a firm should continually encourage employees to accept education and training. The QMS aspiration of continuous improvement in meeting customer requirements is supported by a thorough learning orientation, including substantial investments in training and the widespread use of statistical and interpersonal techniques designed to promote individual and team learning (Al-Ababneh, 2011). According to Deming (1986), Japanese firms obviously regard their employees as their most significant competitive assets and provide good general orientation as well as training in specific skills. The investment in employee's training is to pursue long-term overall business excellence. In fact, employees are valuable resources worthy of receiving training throughout their career development.

\section{Reward and Recognition}

Recognition is defined as the public acknowledgment of superior performance of specific activities (Zahid, 2014). Reward is defined as benefits such as increased salary, bonuses and promotion, which are conferred for generally superior performance with respect to goals (Juran, 1999). Public recognition is an important source of human motivation. It almost goes without saying that an important feature of any quality improvement program is the showing of due recognition for improved performance by any individual, section, department or division within the organisation (Deming, 1986). To effectively support their quality effort, firms must implement an employee's compensation system that strongly links quality and customer satisfaction with pay. Deming (1986) and Ishikawa (1985) identified one source of human motivation at work as social motivation, the energy that comes from cooperation with others on a shared task and the incentive provided by recognition from others. A large majority of firms implementing QMS modify their performance measurement and reward systems so that achievement of specific quality goals can be assessed and rewarded (Berk, 2002). QMS implementation relies increasingly on performance measurement and performance contingent rewards to motivate and control employees. According to the review results by Cherng Yee (2018), 85\% of QMS firms have developed programs to reward individuals and teams for quality achievements. Daud et al., (2012) stated that punishment is a behaviour modification strategy. Punishment is the presentation of an undesirable consequence or the removal of a desirable consequence because of unacceptable behaviour, and is regarded as negative motivator. Zhang (2000) further proposed that a reward and recognition system should be equitable. Workers who achieve the same level of performance should receive comparable rewards. Similarly, workers who fail to obtain certain levels of performance should receive comparable punishment. In this regard, 
INTERNATIONAL JOURNAL OF ACADEMIC RESEARCH IN BUSINESS AND SOCIAL SCIENCES

Vol. 9, No. 1, Jan, 2019, E-ISSN: 2222-6990 ㄷ 2019 HRMARS

punishment is a special recognition and 'reward' for employees who do not perform well (Irianto, 2005). It is important to note that employee's recognition and rewards should be based on equity. Effective recognition and reward activities can stimulate employees' commitment to the firm.

\section{Summary of Literature Review}

After the review of four main human factors, it was evident that each factor has its own distinctive relationship. Their intuitions offer a solid foundation for conducting this study and it can be summarised as follows:

a. It is management responsibility to provide commitment, leadership, empowerment, encouragement, and the appropriate support to technical and human processes. It is top management responsibility to determine the environment and framework of operations within a firm.

b. It is imperative that the participation of the employees in QMS, and develops a quality culture by changing perception and attitudes toward quality.

c. The importance of employee's training is emphasised in changing employees' belief, behaviour, and attitudes; enhancing employees' abilities in carrying out their duties.

d. Employees should be rewarded for their quality improvement efforts.

\section{Research Framework}

The comprehensive literature form the basis of this research conceptual framework.

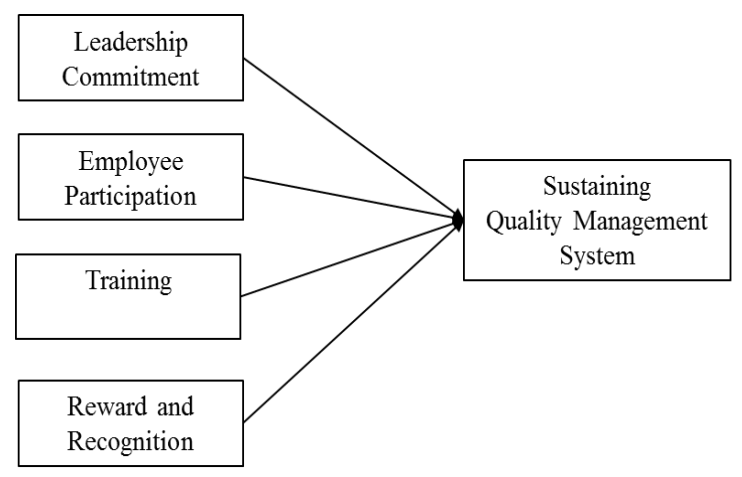

Figure 1: The Conceptual Framework

\section{Methodology}

This study employs quantitative research method using questionnaire survey. Questionnaire survey allows collection of large amount of data from a sizeable population in a highly economical way. Collected data are standardised, easy to understand and allows easy comparison. It gives more control over the research process. Data collected by this method may not be as wide ranging as those collected by qualitative research methods. 


\section{Data Collection}

This study focusses on military personnel throughout Peninsular Malaysia who are directly involved in QMS. A purposive sampling method was adopted to collect data from officers and other ranks. A total of 350 questionnaires were distributed to the respondents and 300 valid questionnaires were collected. Data was collected using pre-designed and structured questionnaires. Before the actual survey were conducted, the questionnaires were pre-tested and reviewed for structure, readability, ambiguity and completeness, and the survey instrument was refined in light of comments from the respondents. Data for the questionnaire was developed by reviewing journals, media articles, internet documents and information, and relevant publications and personal observations in military organisations. The questionnaire contains five (5) parts: Leadership commitment, Employee's participation, Training, Reward and recognition; and Sustaining QMS. The respondents were asked to rate the answer of each question on a five-point Likert-type scale ranging from one (1) (Strongly Disagree) to five (5) (Strongly Agree) to what extent the statement fits the situation in their organisation.

\section{Data Analysis}

SPSS version 23 was used to provide a descriptive statistical analysis of participant demographics. The Pearson's correlation coefficient was used to analyse the relationship between Leadership commitment, Employee's participation, Training; Reward and recognition; with Sustaining QMS. The regression was chosen to identify the extent of Leadership commitment, Employee's participation, Training, Reward and recognition with Sustaining QMS.

\section{Result and Discussion}

The Relationship between Leadership Commitment, Employee's Participation, Training and; Reward and Recognition with Sustaining QMS

The relationship between Leadership Commitment $\left(X_{1}\right)$, Employee's Participation $\left(X_{2}\right)$, Training $\left(X_{3}\right)$ and; Reward and Recognition $\left(\mathrm{X}_{4}\right)$ with Sustaining QMS $(\mathrm{Y})$, was investigated using Pearson productmoment correlation coefficients. Preliminary analyses were performed to ensure no violation of the assumptions of normality and linearity. Since there were four (4) Bivariate pairs, the Bonferroni Adjusted Alpha of $0.0125(0.05 / 4)$ was used to test null hypothesis of the bivariate correlations. 
INTERNATIONAL JOURNAL OF ACADEMIC RESEARCH IN BUSINESS AND SOCIAL SCIENCES

Vol. 9, No. 1, Jan, 2019, E-ISSN: 2222-6990 @ 2019 HRMARS

Table 1: Zero-order correlations between leadership commitment, employee participation, training and; reward and recognition with sustaining QMS

\begin{tabular}{|c|c|c|c|c|c|c|}
\hline \multicolumn{2}{|c|}{ Variables } & $Y$ & $X_{1}$ & $x_{2}$ & $x_{3}$ & $x$ \\
\hline$Y$ & $\begin{array}{l}\text { Sustaining } \\
\text { QMS }\end{array}$ & 1 & & & & \\
\hline$X_{1}$ & $\begin{array}{l}\text { Leadershi } \\
\mathrm{p} \\
\text { Commitm } \\
\text { ent }\end{array}$ & $\begin{array}{l}0.45 \\
0\end{array}$ & 1 & & & \\
\hline$x_{2}$ & $\begin{array}{l}\text { Employee } \\
\text { Participati } \\
\text { on }\end{array}$ & $\begin{array}{l}0.54 \\
2\end{array}$ & $\begin{array}{l}0.62 \\
6\end{array}$ & 1 & & \\
\hline$x_{3}$ & Training & $\begin{array}{l}0.57 \\
2\end{array}$ & $\begin{array}{l}0.54 \\
4\end{array}$ & $\begin{array}{l}0.67 \\
9\end{array}$ & 1 & \\
\hline$X_{4}$ & $\begin{array}{l}\text { Reward } \\
\text { and } \\
\text { Recognitio } \\
\mathrm{n}\end{array}$ & $\begin{array}{l}0.56 \\
1\end{array}$ & $\begin{array}{l}0.50 \\
0\end{array}$ & $\begin{array}{l}0.55 \\
0\end{array}$ & $\begin{array}{l}0.61 \\
5\end{array}$ & 1 \\
\hline
\end{tabular}

Notes: zero-order coefficients $p<.01$, Bonferroni adjusted alpha $=0.0125(0.05 / 4)$

As depicted in Table 1, the strongest linear relationship was found to exist between training $\left(X_{3}\right)$ with sustaining QMS $(\mathrm{Y})(r=.57, p=.0001)$. The positive correlation coefficient of .57 indicates that as the score for training increases so do the rating for sustaining QMS. The second highest was found between reward and recognition $\left(\mathrm{X}_{4}\right)$ with QMS $(\mathrm{Y})(r=.56, p=.0001)$ and the correlation coefficient of .56 indicates that there was moderate positive linear relationship between reward and recognition (X4) with sustaining QMS. The next highest was between employee participation (X2) with sustaining QMS (Y) ( $r=.54, p=.0001)$ and a value of .54 indicates a moderate positive linear relationship. Finally, leadership commitment (X1) showed a low positive correlation with sustaining QMS (Y) $(r=.45, p=$ .0001). The relationship of human factors with sustaining QMS are supported in this study as suggested by numerous studies (Zhang, 2000). The results of this study suggest that human factors are important towards a sustaining QMS in military organisation.

\section{To Identify to What Extent the Human Factors Related to Sustaining QMS for Military Organisation in Malaysia}

The extent the human factors related to QMS was determined according to regression analysis results. The chosen variables include leadership commitment, employee's participation, training and; reward and recognition. Before undertaking the regression analysis, tests were conducted on the hypothesis which includes normal distribution, independency of independent variables auto correlation and linear modelling goodness of fit. From Table 2, it shows that reward and recognition have the highest reading of .287 for the standardised coefficient and $p<0.05$. Employee's participation has the lowest reading of .185 for standardised coefficient and $p<0.05$. Foregoing results show that 
INTERNATIONAL JOURNAL OF ACADEMIC RESEARCH IN BUSINESS AND SOCIAL SCIENCES

Vol. 9, No. 1, Jan, 2019, E-ISSN: 2222-6990 (c) 2019 HRMARS

reward and recognition are the most significant factor impacting on sustaining QMS while impact of employee's participation is less obvious. This supports the importance of reward and recognition in sustaining QMS as suggested by numerous studies (Mustafa, 2015).

Table 2: The regression coefficient for sustaining QMS

\begin{tabular}{|c|c|c|c|c|c|}
\hline \multirow[b]{2}{*}{ Model } & \multicolumn{2}{|c|}{$\begin{array}{l}\text { Unstandard } \\
\text { ized } \\
\text { Coefficients }\end{array}$} & \multirow{2}{*}{$\begin{array}{l}\text { Stan } \\
\text { dard } \\
\text { ized } \\
\text { Coef } \\
\text { ficie } \\
\text { nts } \\
\\
\text { Beta }\end{array}$} & \multirow[b]{2}{*}{$\mathrm{t}$} & \multirow[b]{2}{*}{ Sig. } \\
\hline & B & $\begin{array}{l}\text { Std. } \\
\text { Erro } \\
r\end{array}$ & & & \\
\hline 1 (Constant) & $\begin{array}{l}1.80 \\
4\end{array}$ & .589 & & $\begin{array}{l}3.06 \\
1\end{array}$ & .002 \\
\hline $\begin{array}{l}\text { Leadership } \\
\text { Commitme }\end{array}$ & .042 & .036 & .063 & $\begin{array}{l}1.16 \\
9\end{array}$ & .243 \\
\hline $\begin{array}{l}\text { nt } \\
\text { Employee }\end{array}$ & & & & & \\
\hline $\begin{array}{l}\text { Participati } \\
\text { on }\end{array}$ & .116 & .039 & .185 & $\begin{array}{l}3.00 \\
5\end{array}$ & .003 \\
\hline Training & .148 & .038 & .235 & $\begin{array}{l}3.86 \\
5\end{array}$ & .000 \\
\hline $\begin{array}{l}\text { Reward } \\
\text { and } \\
\text { Recognitio } \\
n\end{array}$ & .186 & .035 & .287 & $\begin{array}{l}5.33 \\
7\end{array}$ & .000 \\
\hline
\end{tabular}

a. Dependent Variable: Sustaining QMS

\section{Conclusion}

The main findings of this study reveal that leadership commitment, employee's participation, training and; reward and recognition were all positively related to sustaining QMS. Among them, reward and recognition were the most significant human factors in explaining QMS followed by training and employee's participation. In conclusion, these findings can assist the top management of military organisation in Malaysia to better understand the human factors especially in sustaining QMS.

\section{References}

Ab Wahid, R. (2010). Beyond Certification: The Maintenance of ISO 9000 in Malaysian Service Organisations.The University of Waikato. 
INTERNATIONAL JOURNAL OF ACADEMIC RESEARCH IN BUSINESS AND SOCIAL SCIENCES

Vol. 9, No. 1, Jan, 2019, E-ISSN: 2222-6990 @ 2019 HRMARS

Retrieved from http://researchcommons.waikato.ac.nz/handle/10289/4936

Ahmad, M., Zakuan, N., Jusoh, A., Yusof, S., Hisyamudin, M., \& Takala, J. (2013). The Relationships Between The Extent of TQM Practices and The Importance on Business Performance : A Survey in Malaysia. International Conference on Advanced Manufacturing, 8(4), 541-547.

Al-Ababneh, M. (2011). An Exploration of the Effects of Total Quality Management Implementation on Organisational Creativity in the Hotel Industry. Guildford.

Ali, Z. (2013). Developing a Framework to Apply Total Quality Management Concepts to Land Administration (The case of Islamic Republic of Pakistan). University of Twente. https://doi.org/10.1186/s12944-016-0307-3

Berk, J. (2002). Quality Management for the Technology Sector. Newnes. Retrieved from http://db02.linccweb.org/login?url=http://proquestcombo.safaribooksonline.com/?uiCode=br evardcc\&xmlld=0619075562

Cherng Yee, J. (2018). The Influence of Total Quality Management on Project Performance: The Case of Construction Organizations in Malaysia. Curtin University.

Retrieved from https://espace.curtin.edu.au/bitstream/handle/20.500.11937/68411/Jong

CY 2018.pdf?sequence $=1$

Daud, Y., Jamaludin, K. R., \& Ramanr, J. V. (2012). Human Factor Issue in Quality Management. Jurnal Teknologi (Sciences and Engineering), 59 (Suppl 1), 33-35.

Davies, J. (2004). The Implementation of the European Foundation for Quality Management's (EFQM) Excellence Model in Academic Units of UK Universities. University of Salford.

Irianto, D. (2005). Quality Management Implementation: A Multiple Case Study in Indonesian Manufacturing Firms. University of Twente, The Netherlands.

Juran, J. M. (1999). Juran's Quality Handbook. (A. B. Godfrey, Ed.) (Fifth Edit). New York: McGraw-Hill.

Mustafa, E. M. A. (2015). Impact of Total Quality Management Practices on Innovation in Service Organisations. Universiti Tun Hussein Onn Malaysia.

Ooi, K. B., Bakar, N. A., Arumugam, V., Vellapan, L., \& Loke, A. K. Y. (2007). Does TQM Influence Employees' Job Satisfaction? An Empirical Case Analysis. International Journal of Quality and Reliability Management, 24(1), 62-77. https://doi.org/10.1108/02656710710720330

Samat, N. binti. (2004). The Relationship Between Total Quality Management (TQM) Practices, Service Quality, Market Orientation and Organizational Performance. Universiti Utara Malaysia.

Toga, M. (2017). The Relationship between Total Quality Management and Innovation in the South African Foundry / Steel Industry. University of the Witwatersrand.

Zahid, et al. (2014). An Empirical Study on Total Quality Management Practices in Some Selected Manufacturing Companies in Bangladesh. International Journal of Ethics in Social Sciences, 2(1), 95-112.

Zhang, Z. (2000). Implementation of Total Quality Management: An Empirical Study of Chinese Manufacturing Firms. Labyrint Publication. https://doi.org/10.1080/09544129000000046 